\title{
Representações femininas em Game of Thrones: mediações entre os Sete Reinos e a Contemporaneidade ${ }^{1}$
}

\section{Andréa Corneli Ortis}

Doutoranda; Universidade Federal de Santa Maria, Santa Maria, RS, Brasil ORCID: https://orcid.org/0000-0002-9865-8411

\section{Flavi Ferreira Lisbôa Filho}

Doutor; Universidade Federal de Santa Maria, Santa Maria, RS, Brasil ORCID: https://orcid.org/0000-0003-4307-9401

\begin{abstract}
Resumo
A presente pesquisa questiona como são representadas as identidades femininas da personagem Sansa Stark, de Game of Thrones, e quais sentidos sobre o feminino contemporâneo são mobilizados pela série. Para isso, buscamos observar nosso objeto através da categoria personagem e interações por meio da análise textual proposta por Casetti e Chio (1999). Após isso, acionamos o conceito de mediação, advindo de um cotejamento entre Williams (1979), Orózco-Gómez (1997) e Martín-Barbero (2001), por meio das categorias gênero, competência e moralidade pública, e percebemos que a série busca problematizar tipos de violência que acontecem na contemporaneidade em relação ao feminino, como sexual, psicológica ou física, casamento infantil e mulher como moeda de troca. Assim, ao longo das temporadas, a personagem é retratada de modo a ascender, porém somente após passar por inúmeros tipos de violência. Portanto, os sentidos negociados entre a ficção e a realidade presentes em Sansa, na série, são formadas de acordo com o ambiente em que vive, valores sociais e privados impostos pela sociedade.
\end{abstract}

\section{Palavras-chave}

Identidade feminina. Gênero. Representação. Mediações. Game of Thrones.

\section{Introdução}

É cada vez mais difícil tornar-se mulher na sociedade contemporânea, fato que vai de encontro aos tantos anos de lutas que foram travadas para tentar vivermos de maneira

\footnotetext{
${ }^{1}$ Este trabalho é um recorte da dissertação de mestrado de mesmo título. A pesquisa completa pode ser acessada aqui: https://bit.ly/2nX1dxY.
} 
igualitária, em que homens e mulheres possam ter os mesmos direitos, bem como receber o mesmo tratamento.

Esse abismo que separa homens e mulheres é visível tanto em aspectos profissionais, quanto em financeiros e sociais. Segundo o Relatório da Desigualdade Global de Gênero de 2017 (The Global Gender Gap Report 2017), o acesso à educação e à saúde, o empoderamento econômico, a sobrevivência e a oportunidade econômica não são os mesmos para homens e mulheres. No patamar político, por exemplo, apenas $20 \%$ das mulheres são congressistas, $18 \%$ atuam como ministras e $47 \%$ dos países já tiveram uma mulher como chefe de Estado. Em países em desenvolvimento, os índices referentes à presença feminina no mercado de trabalho são ainda mais impactantes. No norte da África, apenas $21,9 \%$ das mulheres participam ativamente desta fatia, enquanto a presença masculina é de 71,9\%. Já na América Latina e no Caribe, os números sobem um pouco, porém, ainda são considerados baixos: o porcentual é de 51,5\% mulheres no mercado de trabalho para $77,1 \%$ de homens. 0 mesmo relatório, ainda, indica que a desigualdade de gênero no mundo só acabaria em cerca de 100 anos e, no mercado de trabalho, esse tempo aumenta para 217 anos.

Devido à falta de equidade, compreendemos que estudar a representatividade da mulher, especialmente na mídia, é extremamente importante, afinal, a misoginia está fortemente enraizada na sociedade contemporânea. Os Estudos Culturais, neste contexto, valorizam os discursos marginais, a cultura dos subalternos e se tornam importantes para esta pesquisa, pois, enaltecem estudos de gênero e da mulher, os quais estão amplamente interligados com questões culturais.

\footnotetext{
"Tem como referência, em particular, o esforço para retirar o estudo da cultura do domínio pouco igualitário e democrático das formas de julgamento e avaliação que, plantadas no terreno da 'alta' cultura, lançam um olhar de condescendência para a não-cultura de massas". (JOHNSON, 2006, p. 20).
}

Assim, os estudos de gênero fazem parte desta perspectiva teórica, afinal, o conceito é uma construção embasada na cultura e sociedade, a qual tem por costume diferenciar feminino e masculino pelos seus atributos biológicos.

Para os Estudos Culturais, essas práticas sociais estão intrinsecamente conectadas à cultura e podem ser estudadas a partir de um ponto de vista cultural e, nesse contexto, se 
enquadra o trabalho que a mídia e seus modos de consumo desempenham (JOHNSON, 2006). Além disso, para o campo, as narrativas audiovisuais, especialmente a televisão - e também as séries -, são um dos principais locais por meio dos quais a cultura circula e é produzida, fazendo com que o discurso televisivo não seja neutro, afinal, está atrelado às estruturas de produção de sentido (HALL, 2003).

Tamanha pertinência da representação feminina nos motivou a realizar a presente pesquisa, que tem como tema identidades femininas em uma série televisiva com foco na construção de sentidos da mulher contemporânea a partir de uma das personagens de Game of Thrones². Assim, a questão norteadora do presente estudo pode ser sintetizada no seguinte enunciado: Como são representadas as identidades femininas da personagem Sansa Stark, de Game of Thrones, e quais sentidos sobre o feminino contemporâneo são mobilizados?

Na primeira parte do texto trazemos a perspectiva dos estudos de gênero para, posteriormente, analisarmos, por meio da análise textual, proposta por Casetti e Chio (1999), como se dá a representação feminina na série. A partir desta análise, acionamos o conceito de mediação, compreendido como uma interpretação da realidade de acordo com Orózco-Gómez (1997), Williams (1979) e Martín-Barbero (2001), observada a partir de três de sentidos: gênero, competência e moralidade pública para identificar como ocorrem as mediações entre essa representação e a contemporaneidade.

\section{Estudos de Gênero}

Os lugares ocupados por homens e mulheres não são os mesmos. Aos homens é reservado o espaço da liderança, comando, virilidade, força e racionalidade. Em contrapartida, doçura, delicadeza e fragilidade compete ao feminino. Esse pensamento pode ser associado à percepção sobre o gênero feminino presente em nosso senso-comum, o qual relaciona mulheres à fragilidade e como um reflexo da inconsistência emocional feminina. Por isso, "[...] a construção de uma mentalidade que acredita que a fragilidade se associa à incapacidade feminina ainda é algo naturalizado." (BORGES; RODRIGUES, 2018, p. 122).

\footnotetext{
2 A série Game of Thrones teve sua estreia em 2011, no canal HBO, e tem como enredo a luta dinástica de famílias pelo poder, representado pelo Trono de Ferro. É uma produção campeã de audiência, com 18,4 milhões de telespectadores (as) em todas as plataformas de exibição do canal norte-americano durante sete temporadas. A oitava, e última temporada da trama, foi ao ar em 2019 e, segundo a HBO, teve uma média 44,2 milhões de espectadores por episódio (O GLOBO, 2019).
} 
O espaço doméstico sempre foi associado ao feminino justamente pelo fato de a mulher dar à luz e exercer a maternidade. Assim, enquanto os homens trabalhavam fora para prover, financeiramente, a família, a mulher cuidava do lar e dos filhos. Isso foi considerado como natural por muito tempo, fato que acabou culminado na submissão do feminino ao masculino ${ }^{3}$. No entanto, a concepção da mulher estar restrita ao lar mudou no momento em que foi necessária sua inserção no universo público devido ao surgimento da indústria, em que há uma demanda de mais serviços e torna-se necessária uma mão de obra quantitativamente superior que a fornecida somente pelo sexo masculino. Assim, abriu-se espaço para uma participação ativa da mulher no trabalho industrial. Essa inserção fez com que o conceito de gênero passasse a ser estudado como forma de tentar desmistificar essas redes de submissão as quais as mulheres são impostas, diariamente.

As primeiras tratativas oficiais sobre o conceito gênero foram trazidas pelo psicanalista Robert Stoller, em 1963 (HARAWAY, 2004), o qual formulou o termo identidade de gênero para mostrar que a palavra sexo está relacionada à biologia, enquanto gênero tem ligação com a cultura. "O produto do trabalho da cultura sobre a biologia era o centro, a pessoa produzida pelo gênero - um homem ou uma mulher." (HARAWAY, 2004, p. 216).

No entanto, a problematização do conceito ganhou visibilidade durante a segunda onda feminista4, no final dos anos 1960, período marcado pelas lutas por direitos ao prazer e ao corpo. Nesta época, iniciaram questionamentos acerca do universalismo masculino, os quais eram atravessados por confrontos e resistências "[...] com aqueles e aquelas que continuavam utilizando e reforçando justificativas biológicas ou teológicas para as diferenças e desigualdades entre homens e mulheres [...]" (LOURO, 2007, p. 13). Porém, as questões de gênero somente ganharam centralidade na terceira onda feminista, nos anos 1990. Segundo Ana Carolina Escosteguy (2016, p. 70),

[...]o entendimento da categoria 'gênero' como construção social se associa à ideia de que as identidades se definem de modo relacional e, a partir de

\footnotetext{
${ }^{3}$ Um dos principais responsáveis por essa submissão é conhecido como mito da criação. De acordo com este, a mulher é a responsável pela expulsão da humanidade do paraíso por ceder às tentações ao comer o fruto proibido, passando de doadora de vida à "[...] primeira e a maior pecadora, a origem de todas as ações nocivas ao homem, à natureza e aos animais." (MURARO, 1991, p. 16) na mitologia judaico-cristã

${ }^{4}$ Quatro ondas feministas são reconhecidas em nível global. A primeira, no século XIX, reivindicava o direito ao voto e â educação. A segunda clamava pela liberdade do corpo e sexualidade. Na terceira, o conceito de gênero passa a ser central nas discussões feministas, e a quarta centra-se na virada do século XXI e traz à baila o conceito de pós-feminismo (ESCOSTEGUY, 2016), compreendido como antifeminista (MODLESKY, 1991).
} 
determinado momento, não mais exclusivamente via o par femininomasculino. 5

Assim, a palavra gênero, de acordo com Piscitelli (2009, p. 119), foi elaborada por feministas justamente para "[...] desmontar esse duplo procedimento de naturalização mediante o qual as diferenças que se atribuem a homens e mulheres são consideradas inatas, derivadas de distinções naturais [...]". Essas, por sua vez, são facilmente compreendidas por meio do uso da palavra sexo, a qual remete às diferenças biológicas. E, como efeito cascata, as desigualdades existentes entre uns e outros são vistas como resultado dessas diferenças, portanto, entre masculinidades e feminilidades. Para Heilborn (1994, p. 2), essa diferenciação entre os gêneros é produzida por meio de um sistema de representações

A cultura composta de conjuntos ideacionais específicos apresenta-se como um todo integrado; cada domínio pode ser objeto de concepções peculiares, contudo eles mantêm entre si uma tessitura que não é de simples justaposição, ao contrário, integram um sistema interdependente que provê a coerência de uma determinada visão de mundo. (HEILBORN, 1994, p. 2)

Gênero surge, portanto, como uma tentativa de mostrar que diferenciar homens e mulheres por suas características biológicas é um fenômeno cultural e, consequentemente, uma construção social. Para Garcia (2011, p. 19), o conceito pode ser compreendido como um conjunto de "[...] normas, obrigações, comportamentos, pensamentos, capacidades e até mesmo o caráter que se exigiu que as mulheres tivessem por serem biologicamente mulheres.". Assim, gênero não é o mesmo que sexo e sim todas as "[...] normas e condutas determinadas para homens e mulheres em função do sexo." (GARCIA, 2011, p. 20). Esse pensamento vai ao encontro de Joan Scott (1995, p. 75), que entende o termo como "[...] uma categoria social imposta sobre um corpo sexuado.".

Ademais, essa distinção entre os gêneros feminino e masculino se entende para os meios de comunicação, os quais "[...] possuem um status definidor na propagação e/ou desmistificação de construções e interpelações de gênero na esfera cultural." (TOMAZETTI; CORUJA, 2017, p. 2). Sabemos que a mídia pauta seus programas embasada naquilo que a

\footnotetext{
5 É importante lembrar que, no campo dos Estudos Culturais, perspectiva teórica a qual este trabalho se vincula, o conceito de gênero passou a ser estudado por feministas que integravam o Centro nos anos 1970, período entre a segunda e terceira onda feminista.
} 
sociedade está vivenciando e, por isso, é comum que a mulher seja retratada como subordinada, inferior ao homem por ser o sexo frágil, pois essa submissão foi construída socialmente. No entanto, “[...] o que é construído pode ser modificado. Portanto, alterando as maneiras como as mulheres são percebidas seria possível mudar o espaço social por elas ocupado." (PISCITELLI, 2002, p. 2). Assim, nesta pesquisa, buscaremos compreender como é feita a representação identitária da personagem Sansa Stark, de Game of Thrones, se a maneira pela qual é apresentada em um produto audiovisual amplamente difundido em todo o mundo segue o padrão com o qual estamos acostumados a ver, ou se sua representação já abre espaço para a aceitação de novos papéis sociais para as mulheres.

Durante a análise serão trazidas autoras como Butler (2010), Sabat (2003) e Perrot (1998), que abordam aspectos relevantes para a temática de gênero e, de certo modo, complementam esta subseção.

\section{Percurso metodológico}

Para compreender a representação feminina na série, tendo em vista sua adaptação para o meio televisivo, elegemos, primeiramente, a análise textual, de Casetti e Chio (1999), como procedimento analítico. Assim, será necessário observar as imagens, os discursos (falas da personagem) e a personagem em si para entender como a identidade, a qual significa o "[...] processo de construção na qual os indivíduos definem a si mesmos em estreita interação simbólica com outras pessoas."6 (LARRAÍN, 2003, p. 32, tradução nossa) se relaciona com a representação. Por representação, compreendemos que se trata de uma prática que se vale de objetos materiais e efeitos. No entanto, o sentido que transmite depende de sua função simbólica (HALL, 2016)7.

Desse modo, Casetti e Chio (1999) entendem a análise textual como um método que valoriza o material simbólico (signos, símbolos e figuras) de um produto em relação a seus componentes específicos, o que produz diferentes efeitos de sentido. São valorizados aqui os elementos estruturais e qualitativos dos programas.

Para os referidos autores, o esquema de leitura é o instrumento utilizado para organizar e compreender o objeto a ser analisado, bem como suas características. Este

\footnotetext{
6 No original: "[...]proceso de construcción en la que los individuos se van defi niendo a sí mismos en estrecha interacción simbólica con otras personas." (LARRAÍN, 2003, p.32).

7 Devido ao fato de nossa pesquisa estar relacionada à representação da mulher, podemos utilizar como exemplos as formas pelas quais estas são apresentadas na mídia: ou são mulheres reservadas à dedicação exclusiva da casa, filhos e marido, ou, ousadas por resolverem romper essa barreira do que é certo ou errado para a sociedade em que vivem.
} 
esquema pode ser uma lista dos pontos mais importantes do texto ou ter uma forma mais estruturada. Devido ao fato de nosso objeto tratar-se de um produto audiovisual ficcional, elegemos a primeira possibilidade para criarmos nossa própria subcategoria personagem e interações, na qual analisaremos a personagem de Sansa Stark, como acontece o processo de transição de suas identidades ao longo das temporadas, figurinos e como reage aos fatos presentes na trama. Além disso, são observadas, principalmente, as falas da personagem. Ainda, controle dos espaços e ambientação são importantes vetores para compreendermos a representação feminina.

Em prosseguimento, acionamos o conceito de mediação, segundo Williams (1979), Orózco-Gómez (1997) e Martín-Barbero (2001), para verificar quais são as mediações existentes entre personagem e contemporaneidade. Para Williams (1979, p. 101), a mediação corresponde ao "processo de relação entre 'sociedade' e 'arte"', mostrando-nos que dificilmente encontraremos a realidade refletida na arte, afinal, a mediação faz com que o original seja modificado. Martín-Barbero (2001, p. 304) corrobora ao tratar o conceito como "[...] os lugares dos quais provêm as construções que delimitam e configuram a materialidade social e a expressividade cultural da televisão.". São, desse modo, as posições geradas a partir das concepções e significados relacionados à mídia, os quais têm como fonte, por exemplo, o mundo do trabalho, política e produção cultural. Assim, as mediações servem como uma negociação de sentidos entre o que é veiculado pela mídia e o que acontece nos bastidores - na sociedade. Para Orozco Gómez (1997), as mediações possuem caráter múltiplo e, portanto, não existe uma única mediação.

A etnia, o gênero, as identidades do público, as instituições sociais a que pertence e os movimentos e organizações cidadãos dos quais participa, são também mediações que estão moldando o resultado de suas interações com a mídia. (OROZCO-GÓMEZ, 1997, p. 27, tradução nossa). ${ }^{8}$

Levando em consideração, portanto, que a mediação nos auxilia na interpretação da cultura vivida, julgamos ser pertinente criar subcategorias próprias para analisar o conceito de mediação associado à série Game of Thrones. Para isto, utilizaremos as subcategorias de: a) gênero, abordando como este fator é determinante para inferiorizar a personagem; b)

\footnotetext{
8 No original: "La etnia, el género, las identidades de la audiencia, las instituciones sociales alas que pertenece y los movimientos y organizaciones ciudadanas en las que participa, son también mediaciones que van conformando el resultado de sus interacciones con los médios." (OROZCO-GÓMEZ, 1997, p. 27).
} 
competência, como valor do feminino público; e c) moralidade pública, levando em consideração como esta pode mudar para se adaptar à sociedade atual.

Realizamos uma observação flutuante da série Game of Thrones, considerando o universo de episódios que compõem as sete primeiras temporadas, totalizando 67 episódios. Devido à grande quantidade, optamos por selecionar as cenas consideradas mais relevantes para compreender, ainda que parcialmente, os elementos centrais utilizados na narrativa audiovisual na representação do feminino por meio da construção da identidade da personagem. Assim, extraímos aqueles que contribuíssem para a compreensão da representação das identidades femininas que são associadas à personagem Sansa na narrativa, além de quais sentidos sobre o feminino contemporâneo são mobilizados pela série. Portanto, a análise centra-se na personagem e em sua trajetória de modo a entender que pautas feministas da contemporaneidade são associadas à sua figura ${ }^{9}$. Definimos para nosso corpus um total de sete cenas de Sansa. Destacamos que a escolha se deu por meio da análise da trajetória individual da personagem e, por isso, foram selecionados os episódios que contribuíssem para a compreensão dessa trajetória e que constituíssem marcos muito importantes na vida dela.

\section{Quem é Sansa Stark?}

Sansa Stark é a filha mais velha de Catelyn e Eddard Stark. É bonita, educada, dócil, bem arrumada, destaca-se no bordado e tem como sonho casar-se com um príncipe. É o padrão ideal de mulher imposto pela sociedade da trama ${ }^{10}$. Logo no início, no primeiro episódio da série, ela demonstra ter como objetivo de vida casar-se com o filho do atual rei, o príncipe Joffrey Baratheon. Para Caroline Spector (2015, p. 119), mesmo que ela aparente estar apaixonada pelo garoto, “[...] o que ela realmente ama é o mito central de sua cultura um rei gentil e sábio, príncipes nobres e bons, damas que devem ser belas e se comportar de maneira elegante.". Assim, Sansa é aquilo que todos desejam de uma garota: que aceite sua condição como mulher e que seja, portanto, submissa a um universo dominado pelo

\footnotetext{
9 Embora Game of Thrones seja uma série alusiva à nossa Idade Média, traremos, na análise, dados e reflexões das pautas feministas na contemporaneidade associadas à ficção, justamente para compreender onde a série busca inspiração para seu enredo.

${ }^{10} \mathrm{Em}$ muitos casos, a existência das personagens femininas fica condicionada ao matrimônio devido ao período em que a série faz alusão, o medievo. Segundo Macedo (2002), a mulher desta fase era constantemente relegada ao domínio do masculino que a cercava, seja como filha, esposa ou como mãe. Assim, era extremamente importante que se casasse e, mesmo que fosse proveniente de uma família com posses, o dote seria administrado pelo marido, reafirmando a relação de dependência da mulher ao homem.
} 
masculino sendo resultado de "[...] um conjunto de atos repetidos no interior de uma estrutura reguladora altamente rígida, a qual se cristaliza no tempo para produzir a aparência de uma substância, de uma classe natural de ser." (BUTLER, 2010, p. 59).

A Figura 1 mostra a personagem questionando sobre casamento. Na primeira, pergunta à mãe se o príncipe Joffrey irá gostar dela. "E se ele pensar que eu sou feia? Ele é tão bonito. Quando será que nós casaremos? Em breve? Ou vamos ter que esperar?" são alguns dos questionamentos da jovem à mãe, que apenas rebate dizendo que, se ele não quiser, é o príncipe mais estúpido que já viveu. Não satisfeita, Sansa ainda argumenta: "Por favor, por favor! É a única coisa que eu já quis". Assim, o uso do se demonstra uma grande preocupação da menina sobre o que ele, o príncipe, vai pensar dela. Já o quando mostra a expectativa que ela tem em se casar com ele, por isso precisa saber o dia que seu sonho se concretizará, finalizando com a súplica ao implorar e dizer que é a única coisa que já quis.

Figura 1- Sansa pergunta à mãe se Joffrey irá gostar dela

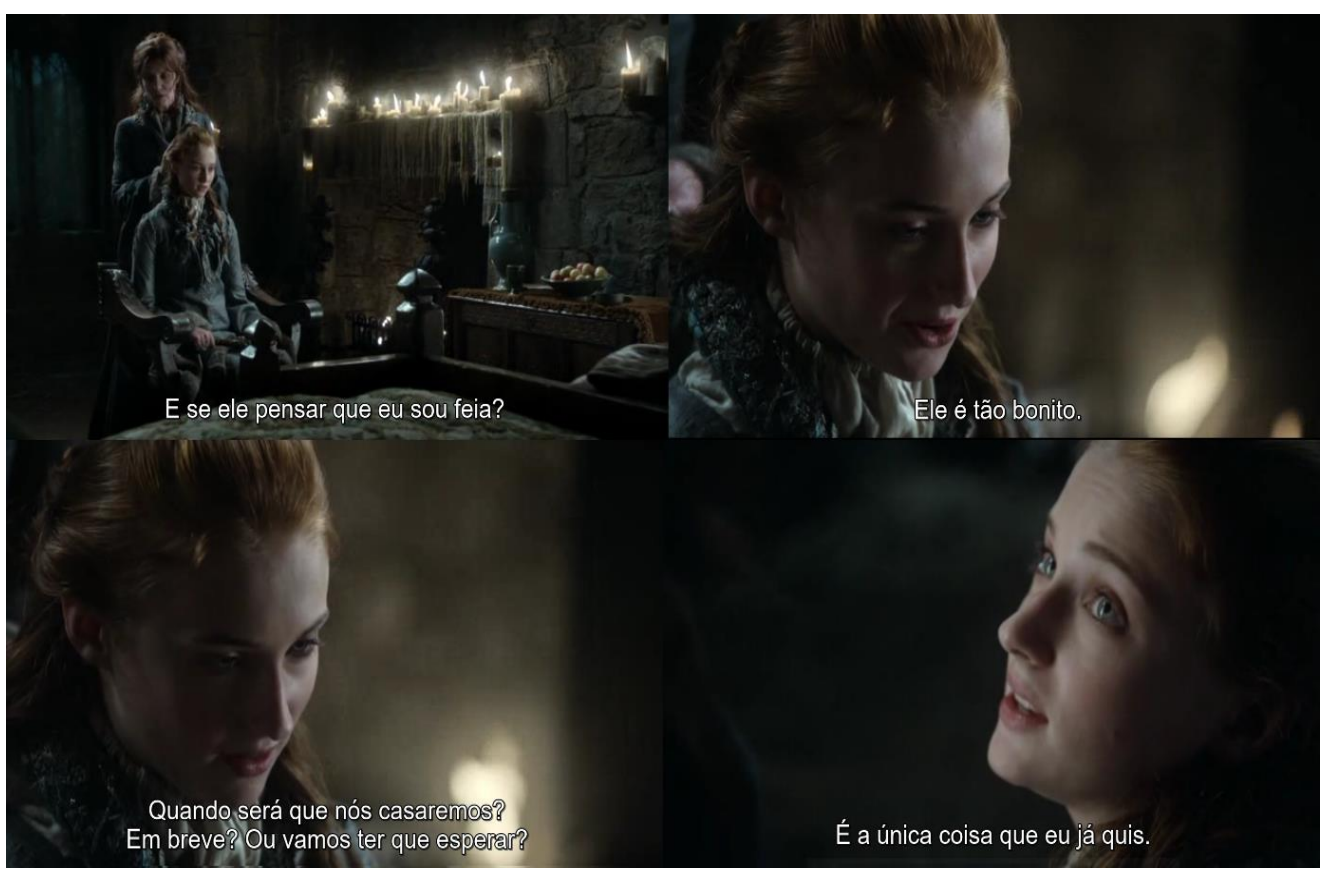

Fonte: HBO.

Pelo diálogo entre as duas, podemos perceber que o sonho de Sansa é casar-se com um príncipe, o qual poderá ser rei no futuro e sua maior preocupação é que ele não goste de sua aparência. Esse ideal de vida requerido pela personagem pode ser classificado como 
complexo de cinderela, termo utilizado, pela primeira vez, nos anos 1980, pela psicóloga Colette Dowling. Segunda a autora (2002, p. 13), “[...] as mulheres são ensinadas a crer que, algum dia, de algum modo, serão salvas.". Esse pensamento vai se consolidando ao longo dos anos e, quando a mulher chega na idade adulta, desenvolve um sentimento de inferioridade e incapacidade e nutre, então, o desejo de ser cuidada e protegida. Para Colette Dowling (2002, p. 26), o complexo de cinderela pode ser compreendido como "[...] uma rede de atitudes e temores profundamente reprimidos que retém as mulheres numa espécie de penumbra e impede-as de utilizarem plenamente seu intelecto e criatividade [...]", como se esperassem por algo para transformar suas vidas.

Essa transformação de vida que a autora explica seria, portanto, o casamento com o príncipe encantado - no caso de Sansa, a união com Joffrey -, aquele que resolveria seus problemas e melhoraria sua vida. Tem-se, portanto, o homem como o salvador. Essa ânsia da jovem fica explícita ao mostrar seu rosto bem de perto, o que traz intimidade e nos aproxima da personagem, demonstrando uma súplica. Esse sentimento está explícito pela expressão dos olhos, que transmite a necessidade de querer que seu desejo seja atendido. Esse sentimento, portanto, poderia ser considerado na questão identitária, já que parece que a personagem, por exemplo, precisa casar-se para ser, de fato, alguém, possuir uma identidade. Além disso, o uso da cor cinza em seu vestido também remete a esse ideal requerido, pois pode significar que não está vendo cores em sua vida, que tudo está sem graça e que, portanto, precisa que a união ocorra para que sua vida tenha brilho e para ser mais reconhecida perante a sociedade da qual ela faz parte. Por essa razão, Sansa Stark pode ser considerada, inicialmente, como uma representação da heteronormatividade no que diz respeito ao "[...] conjunto de normas, regras, procedimentos que regula e normaliza não apenas as identidades sexuais como também as identidades de gênero, estabelecendo maneiras usuais de ser, [...] dirigindo-os ao encontro do gênero/sexo oposto." (SABAT, 2003, p. 68). Portanto, é uma menina criada dentro do padrão heteronormativo, que sonha em se casar com um homem.

Após esse embate com a mãe, Sansa acaba indo morar na capital dos Sete Reinos, Porto Real, junto de seu pai e a irmã, Arya. Para ela, esse novo ciclo representaria a concretização do casamento com o príncipe. Por isso, ao chegar na corte muda seu jeito de se vestir, de se portar, e o cabelo. Começa a usar vestidos que a deixam com ar de adulta. Também começa a questionar sobre os deveres matrimoniais que as esposas deveriam ter 
com os maridos, especialmente no que diz respeito a ter filhos. A garota sabe que precisaria ter filhos homens para darem continuidade ao reinado, afinal, uma mulher não podia governar, somente ser do lar, não podendo "[...] ser proprietária ou herdeira, nem possuir dinheiro." (REIMER, 2006, p. 79). Isso nos faz perceber uma relação de sentidos, proposta pela série, com os valores do patriarcado de que a mulher é vista como propriedade do homem - ele é o senhor das terras, escravos, dos filhos e da mulher. Há, portanto, uma valorização do masculino em relação ao feminino. Segundo Muraro (1991), controlando a mulher significa para o homem a possibilidade de controlar a sexualidade feminina.

No entanto, o deslumbramento de Sansa com o príncipe Joffrey dura pouco, pois ele revela ser um sádico ao condenar e mandar executar seu pai. Com a morte do patriarca, Sansa torna-se refém da família real e é torturada tanto psicológica quanto fisicamente por todos que vivem no castelo e, assim, é obrigada a continuar sendo pretendente de Joffrey. A pressão pela qual passa ao precisar viver no castelo e tornar-se mulher do príncipe faz com que a garota viva com medo e, por isso, segue usando vestidos na cor cinza, remetendo ao fato que "[...] gosta de isolamento, e não quer envolvimento." (FREITAS, 2007, p. 9).

Esse medo transforma-se em pavor ao menstruar pela primeira vez, pois aquilo significava que ela estava apta a casar-se e ter filhos. Segundo Moreira e Batista (2016, p. 29), o fenômeno da menstruação "[...] produz comportamentos, emoções e sentimentos que não são, pelo menos exclusivamente, organizados pela biologia, mas, pela interação entre fenômenos biológicos e aspectos culturais e simbólicos [...]", gerando consequências para a vida adulta como a obrigação de ter filhos, inerentemente imposta à personagem. Assim, a primeira reação que tem ao ver o sangue na cama faz com que tire os lençóis imediatamente para esconder das pessoas que viviam no castelo, afinal, ter filhos do futuro rei aterroriza Sansa e, por isso, a Rainha Cersei não podia descobrir, caso contrário estaria ligada à família real para sempre.

A rainha acaba por descobrir o fato, o que deixa Sansa em pânico. No entanto, esse sentimento logo se transforma em alívio, já que Joffrey decide não se casar mais com ela, porque a garota não teria mais utilidade para ele e sua família. Por um breve período, Sansa sonha com a liberdade e em casar-se com outro homem, Sor Loras Tyrell, um cavaleiro oriundo de uma família nobre. Porém, arranja um novo casamento para ela: Tyrion Lannister, um homem mais velho e tio de Joffrey, além de ser anão, o que faz com que seja repudiado por toda a família. Sansa, ao descobrir que deveria se casar com ele, vê seu 
mundo desabar, pois o homem não é quem ela desejaria ter como marido - foge totalmente do estereótipo de um príncipe, alto, com cabelos loiros e bonito que ela sonhava. Assim, os dois acabam se casando em uma cerimônia pomposa e, quando estão sozinhos no quarto, Tyrion diz que o pai o havia mandado consumar o casamento. Sansa toma um gole de vinho, como se precisasse de coragem, e se dirige para perto da cama, começando a se despir. Após apreciar a cena da garota tirando a roupa, Tyrion manda-a parar, dizendo "eu poderia, mas não quero", enquanto Sansa comenta "mas seu pai...", como podemos ver na Figura 2. Ademais, a expressão no rosto da garota demonstra quão insegura estava ao ter de desempenhar aquele papel.

Figura 2 - Sansa se casa com Tyrion

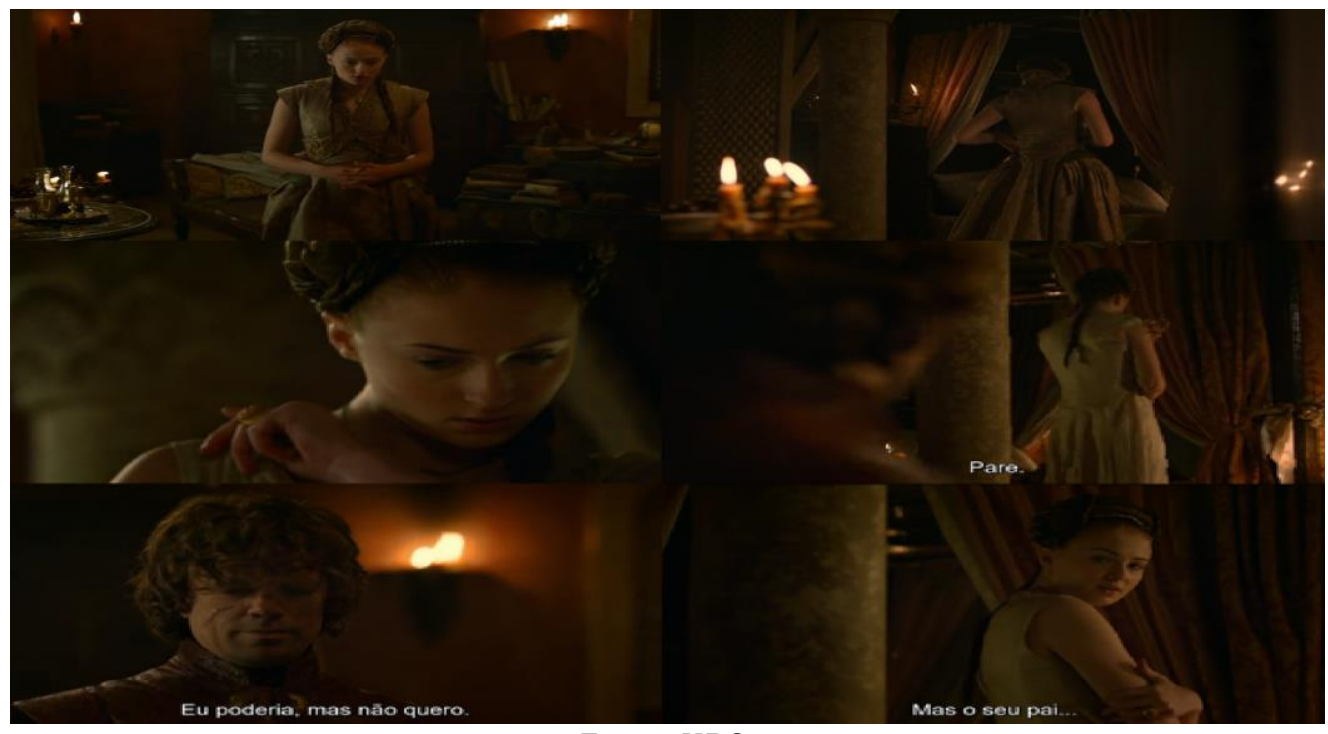

Fonte: HBO.

O fato de Tyrion afirmar que poderia consumar o casamento, mas não quer, pode significar que ele não concorda com aquilo, afinal Sansa tem apenas 14 anos e ele, entre 33 a 38 anos. No entanto, mesmo que a garota tenha somente 14 anos, uma das estratégias da trama, neste momento, é mudar seu cabelo fazendo um penteado diferente, mais elaborado que faz com que aparente ter mais idade. Ainda, o vestido de casamento é sem mangas, diferentemente do que usava nas outras cenas, na cor dourada, com a cintura bem demarcada, além de ter um decote. 0 uso da cor pode ser associado à riqueza e ao ouro, além de ser a cor-símbolo da família do noivo, representada por um leão dourado, subentendendo-se que agora ela é propriedade dele. 
O casamento forçado é associado à sociedade patriarcal em que consideram homens superiores às mulheres. Além disso, há uma série de fatores que influenciam que essa prática seja realizada como pobreza, dotes e também conflitos armados (VARIA, 2015). Esse casamento da trama pode ser associado a um possível conflito armado, pois Sansa e sua família são considerados inimigos da coroa e por isso é mantida como refém, fato que a deixou a mercê da família real e, consequentemente a aceitar tudo que lhe é imposto. Essa submissão a qual a personagem vive pode ser vista ao simplesmente aceitar que terá de dormir com um homem que não gostava e mais velho, pois sabe que não poderá fugir dessa situação. Por isso, tira a roupa e só para quando Tyrion a impede.

Ademais, quando completa a frase de Tyrion "mas seu pai...", pressupõe-se que, para ela, ele deveria obedecer ao pai, já que é quem manda na vida do homem. Portanto, o casamento não é consumado, pois Sansa foi salva por um homem que achava imoral fazer sexo com uma pré-adolescente. Casamentos arranjados entre homens mais velhos e meninas foram considerados comuns por muito tempo. Um dos mais conhecidos da história da humanidade é o de Carlota Joaquina de Bourbon, da Espanha, com Dom João Maria de Bragança, que viria a ser Dom João VI, de Portugal, em 1785. Carlota casou-se com apenas 10 anos com o português, que tinha 18 anos na época. Tal como na série, o casamento entre os dois nobres foi realizado por motivos diplomáticos entre as Coroas Ibéricas (NOGUEIRA, 2019). Atualmente, casamentos contra a vontade ainda são realizados, como no Níger, país da África Ocidental que detém a maior taxa de casamento infantil no mundo, sendo que $76 \%$ se casam antes de completarem 18 anos, conforme dados Girls Not Brides (2017).

No desenrolar da trama, Sansa consegue fugir da família Real. No entanto, acaba sendo manipulada por outro homem, Pety Baelish, um homem obcecado por sua mãe, que a obriga a casar com Ramsey Bolton, um homem brutal e sádico e acaba sendo estuprada na noite de núpcias. Ainda, não bastasse a violência cometida, o homem insiste para que outro jovem, que conhecia Sansa desde pequena, assistisse a tudo e a visse tornar-se mulher. Pela Figura 3, vemos o horror da garota ao saber o que aconteceria. Além disso, é perceptível a fúria do homem ao, literalmente, rasgar seu vestido. Sansa usa, no dia do seu casamento, um vestido branco, cor tradicionalmente usada nas bodas, com peles da mesma cor. 0 branco é associado à pureza e pode querer dizer, muitas vezes, "não me toque" (GROENHOLM, 2010, p. 5) para não ser maculada. Ainda, também pode transmitir a ideia de frieza, que caberia 
para o momento que Sansa passa, ou seja, de precisar se casar, mais uma vez, com alguém que não sente amor nem respeito.

Figura 3 - Sansa é estuprada por Ramsey

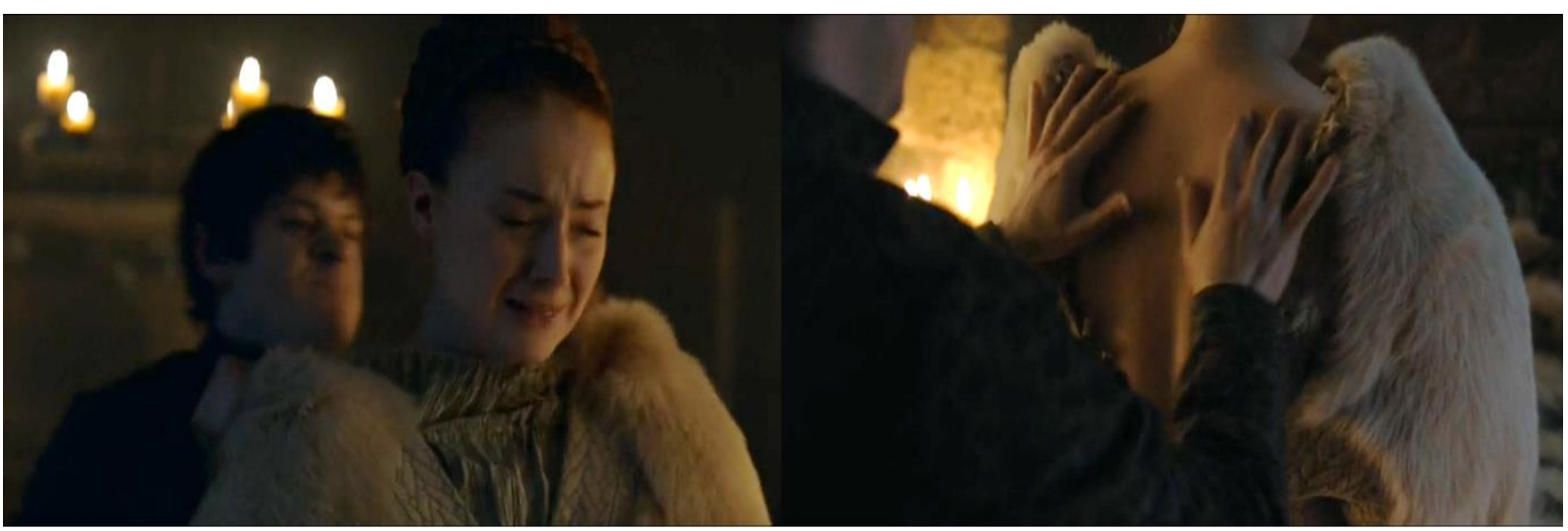

Fonte: HBO.

Nesta parte da trama, novamente aparece a lógica patriarcal, a qual destaca a mulher como propriedade. Predomina, afinal, que Sansa foi vendida por Petyr, que a reconhecia apenas pelo seu valor sexual, e o comprador a estupra por estar exercendo seu direito sobre ela. De acordo com Pereira, Souza e Cardoso (2018, p. 3), a mulher desse período medieval ao qual a série faz alusão "[...] era tida como um objeto ou animal, que servia para parir e satisfazer o homem. Muitas vezes maltratadas, espancadas e estupradas.". Assim, ser estuprada faz parte do seu papel como mulher na época. 0 estupro tem sido utilizado, ao longo dos anos, como uma espécie de gatilho nas séries de televisão na tentativa de penalizar determinada personagem ou para justificar a força. No entanto, essa demonstração gratuita de violência acaba fomentando a chamada cultura do estupro, termo criado na década de 1970, nos Estados Unidos, para mostrar como a sociedade culpa as vítimas da violência pelo ocorrido. É o popular: "ela estava usando roupa curta, então pediu", ou "ninguém mandou provocá-lo". No caso de Sansa, o produtor da série, Bryan Cogman, em entrevista à Hibberd (2015, doc. não paginado), comentou o porquê da cena:

Essa não é uma garota tímida entrando numa noite de casamento com Joffrey. Essa é uma mulher amadurecida fazendo uma escolha e ela vê essa escolha como a forma de recuperar sua terra natal. Sansa tem uma noite de casamento no sentido que ela nunca imaginou que iria com um dos monstros do programa. É bastante intensa e horrível e a personagem terá de lidar com isso. 
De fato, a personagem acaba tornando-se forte após a violência sofrida. No entanto, a cena serve como um trampolim no desenvolvimento de Sansa, como se ela precisasse ser estuprada para encontrar o sentido da vida. Por isso, trazer o estupro à baila em um programa de televisão, campeão de audiência em todo o globo, é problemático no sentido de torná-lo banal, como se as mulheres, por exemplo, precisassem passar por um trauma como esse para ascenderem na vida. Assim, esse tipo de representação na mídia, segundo Moscovici (2003), acaba contribuindo para a construção da realidade, tendo, portanto, papel fundamental nas variações de comportamento, atitudes e modos de agir.

Na série, a personagem, além de ser estuprada na noite de núpcias, segue sendo violentada pelo marido e mantida em cárcere privado. 0 fato é que a violência sexual, bem como a cultura do estupro, está enraizada na trama, a qual busca na sociedade contemporânea a inspiração para suas produções. No desenrolar da história, Sansa e o irmão conseguem retomar Winterfell e fazem Ramsey de refém, deixando-o preso no porão junto com seus cachorros. Sansa, então, aproveita que ele está preso para vê-lo e diz "Suas palavras desaparecerão. Sua casa desaparecerá. Seu nome desaparecerá. Toda memória de você desaparecerá". Pelas palavras da garota podemos inferir que ela está afirmando que tudo o que Ramsey significa desaparecerá. Não se trata, portanto, se uma ameaça, do que poderá vir a acontecer, mas sim de uma sentença: ele morrerá devido a todas as atrocidades que fez com ela. É Sansa que está no comando da situação e tem o poder de decidir o destino dele, sendo uma inversão de papéis já que era ele quem determinava e comandava sua vida e seu corpo - o poder era dele. Ao terminar de falar, os cachorros de Ramsey, famintos ${ }^{11}$, aparecem e acabam comendo-o vivo. Sansa assiste à cena, aos poucos se afasta ao som dos cachorros e do marido gemendo. Ela sorri (Figura 4).

\footnotetext{
${ }^{11}$ Ramsey era conhecido por esfolar as pessoas vivas e também deixar que seus cachorros comessem suas vítimas. Em um dos episódios anteriores, ele falou que havia deixado os animais sem comer durante sete dias e que, portanto, estavam famintos.
} 
Figura 4 - Sansa sorri ao saber que Ramsey morrerá

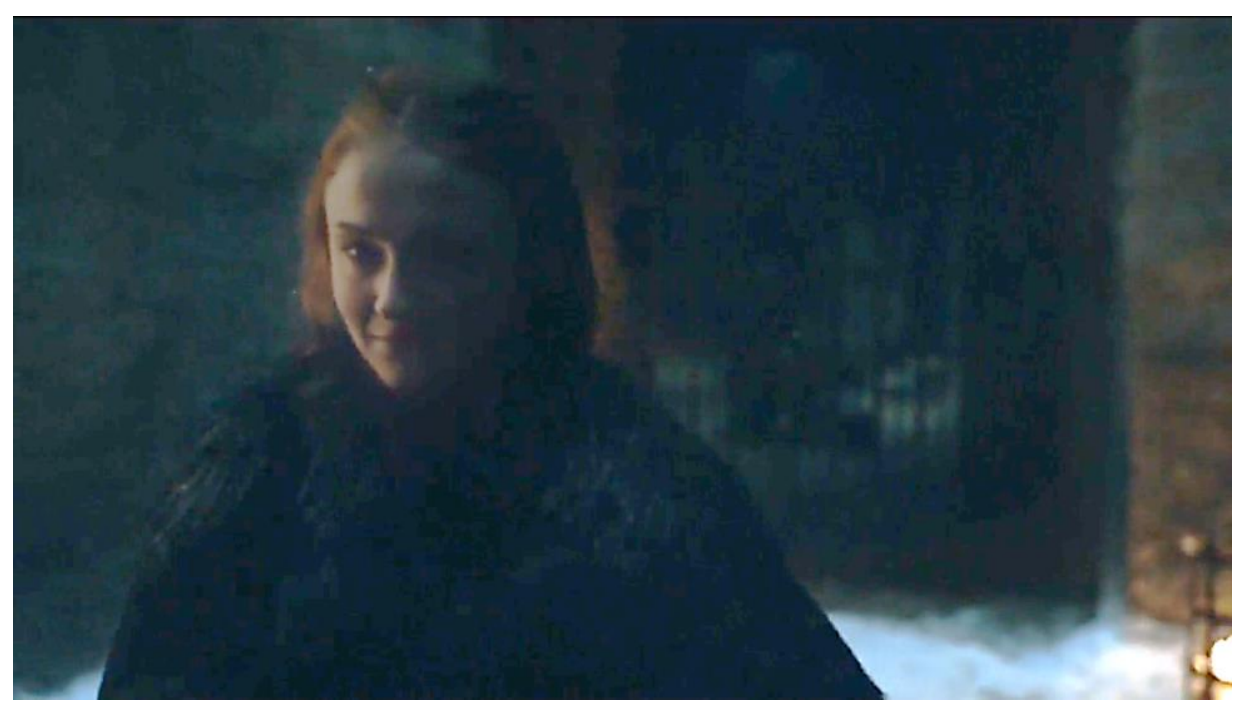

Fonte: HBO.

Ao deixar Ramsey morrer, Sansa faz com que sua moralidade mude. Ou seja, ela rompe uma barreira moral e social, já que matar é um atributo amplamente masculino no universo da série. No momento em que decide o destino de Ramsey, percebemos que a personagem adquire novos valores e novas posturas para se adaptar ao meio em que vive. A morte dele é uma demonstração de força da personagem. Assim, a passagem de Sansa da vida privada ao público a faz adquirir força e, portanto, acentuar certo valor masculino de sua feminilidade. É uma quebra de paradigmas, já que ela adquire valores vistos apenas no universo masculino e compõe o que chamamos de identidade da mulher contemporânea, que é formada de acordo com o ambiente e valores sociais. Portanto, assume para si a competência de agir como um homem, tomar decisões a partir dos regramentos morais estabelecidos por eles para o mundo. Assim, conforme Vieira (2005, p. 14), podemos relacionar a mudança da personagem com sua identidade, a qual

“[...] é aberta, dominada pela incompletude, multiforme. Tem contornos fugidios e adota traços pessoais, culturais e contextuais que se confundem com a sua própria história. A identidade é, por natureza, híbrida e inconstante.".

Essa ascensão pela qual Sansa passa se consolida ao precisar governar Winterfell no lugar de Jon, que precisa sair do local par buscar reforços para uma batalha que está prestes a acontecer. Em meio ao salão principal da residência, Jon diz para todos os presentes, 
representantes de outras famílias, que precisará se ausentar. Sansa, não acreditando no que estava ouvindo, fala "Vai abandonar a sua casa", e Jon responde: "Vou deixar tudo em boas mãos, nas suas. Você é minha irmã, é a única Stark em Winterfell. Até eu voltar, o Norte é seu", conforme a Figura 5. Na imagem também é possível reparar nas roupas de Sansa, que agora são pretas, de couro, e possuem alças. Segundo a figurinista da série, Michele Clapton, em entrevista à revista Time, as fivelas, os cintos e alças de couro que arrematam o vestido simbolizam uma barreira posta pela personagem: o autocontrole sobre o próprio corpo, principalmente depois de ter sofrido violência por inúmeros homens.

Figura 5 - Jon deixa Winterfell nas mãos de Sansa

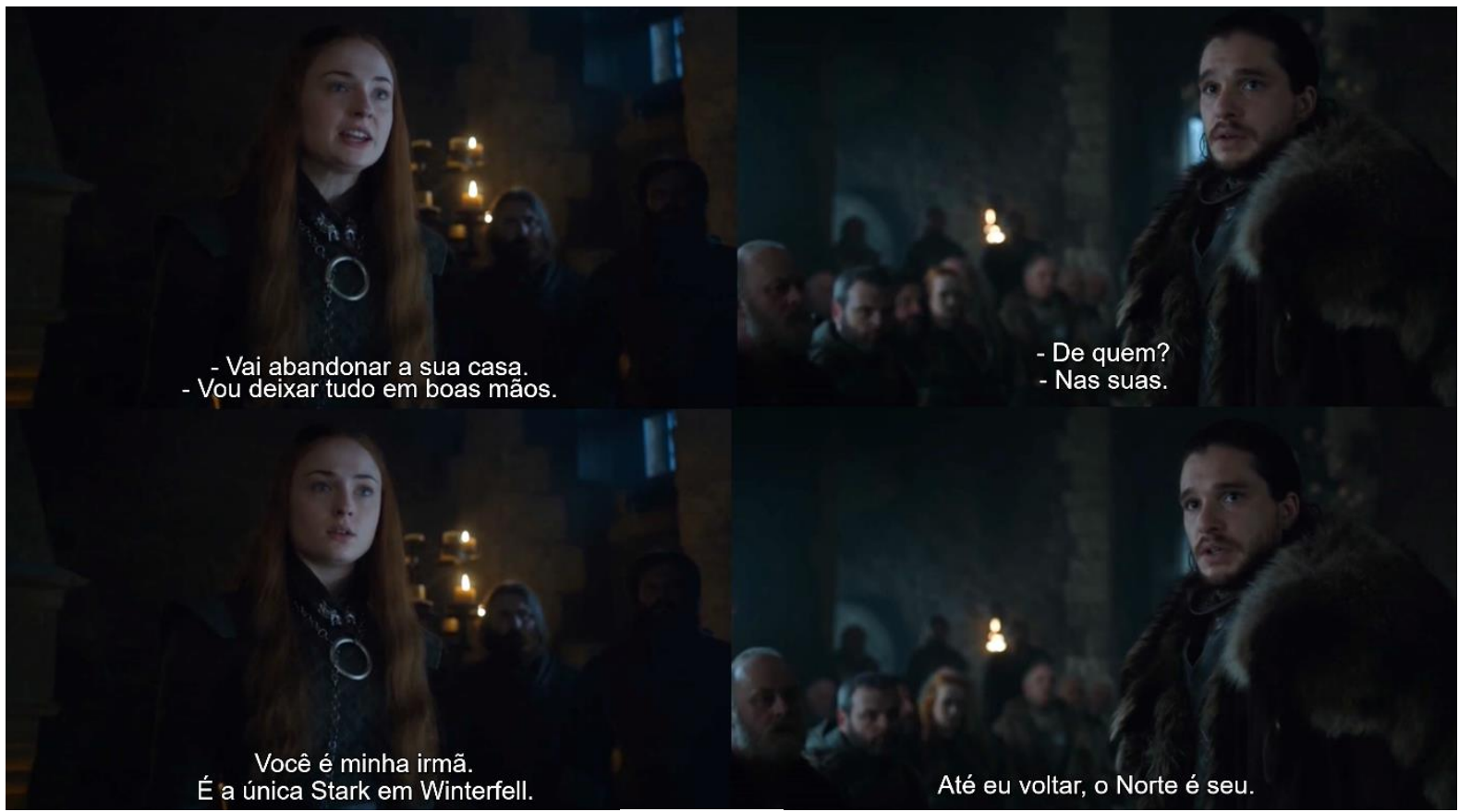

Fonte: HBO.

Ao afirmar que deixará o Norte em boas mãos, Jon demonstra confiar na irmã, mesmo ela sendo uma garota, pelo fato de ser a única representante dos Stark naquele local. Portanto, neste momento, o gênero não importa para ele, e sim ela ser uma Stark. Dessa forma, a moralidade é também um fator decisivo em Sansa na trama, e sua construção aparece marcada pela polarização feminino-privado/masculino-público. Isso reforça, ainda uma vez, o movimento ascendente a que se submete a personagem, que passa da esfera privada do lar, em que servia como moeda de troca, para a esfera pública da liderança. Sansa passa a governar Winterfell, algo inédito para aquela sociedade, acostumada a ter 
somente homens no poder, e demonstra ser competente e ter espírito de líder. No diálogo com um dos conselheiros (Figura 6), questiona se estão deixando as armaduras aptas para o rigoroso inverno que se aproxima. "Não deveriam? Para quando o frio chegar"?, pergunta, e o homem prontamente responde "Deveriam mesmo. Com licença, milady".

Figura 6 - Você nasceu para comandar

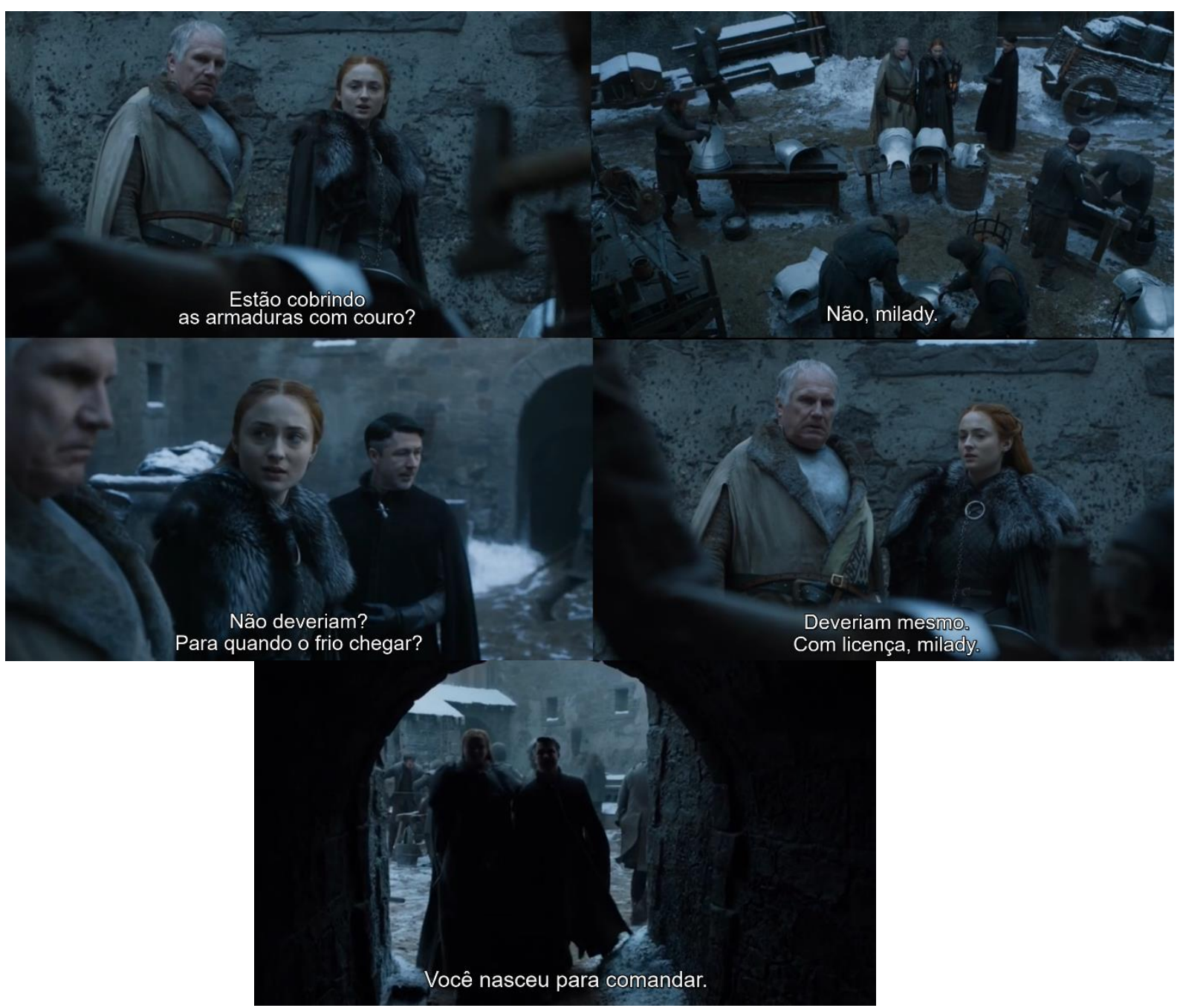

Fonte: HBO.

Ao questionar o homem sobre as armaduras, Sansa demonstra ter conhecimento do armamento que deveria ser utilizado, e o homem prontamente concorda com ela, sinalizando que respeita a opinião, bem como as ordens que ela, uma mulher, está dando. Assim, ao precisar governar Winterfell, muda de roupa: um vestido com partes em pele e adornos de lobos, os quais fazem referência a sua casa e família. Além disso, o cabelo voltou 
a ser dividido ao meio, trazendo um ar de responsabilidade e maturidade. Ao fim, Petyr Baelish, o qual acompanha Sansa, afirma: "Você nasceu para comandar". 0 tom afirmativo dele, assim como o do outro homem, mostra que a reconhecem como líder, e que isso está intrínseco na conduta da personagem, como se, desde pequena, ela soubesse mandar. Essa inserção da personagem significa, para Perrot (1998), que especialmente no mundo ocidental o lugar das mulheres no espaço público sempre foi considerado problemático. Isto porque, enquanto o homem era visto como sujeito eminente e de honra, a mulher pública era vergonhosa, sem individualidade própria.

\begin{abstract}
Mais concreto e material, o "espaço público", amplamente equivalente à cidade, é um espaço sexuado em que os homens e as mulheres se encontram, se evitam ou se procuram. As relações entre eles estão no centro da intriga, mesmo quando se trata, principalmente, como aqui, das mulheres, pois só nessa dualidade se pode entender o lugar delas, nessa relação dinâmica, amorosa ou indiferente, desejante ou conflituosa. 0 espaço ao mesmo tempo a regula e a exprime, a torna visível. (PERROT, 1998, p. 7).
\end{abstract}

Dessa forma, a relação entre o público e o privado de nossa personagem pode ser considerada como uma relação de força e feminilidade, pois ela se enquadra na concepção da mulher contemporânea, já que deixa de ser vista apenas mulher e dona-de-casa, para ser vista como a líder, inserida em um espaço dominado pelo masculino. Assim, podemos dizer que essa relação é resultante de uma mudança de padrões e podemos afirmar que "[...]estão em ascensão hoje a internacionalização, a flexibilidade, a comunicação, a descentralização. Com isso, a nossa própria identidade está comprometida, localizando-nos em um momento de transição." (BERNARDES, 2009, p. 78) - isto é, a identidade da personagem está em transição, por influência do meio em que vive. Assim, Sansa Stark muda sua identidade ao longo da trama: de menina sonhadora, que queria se casar com um príncipe, à senhora de Winterfell, governante de sua casa e também da região. Portanto, a série de televisão, ao representar uma mulher em posição de destaque, “[...] constrói, projeta e estabiliza identidades sociais, em processos definidos histórica e culturalmente." (SGARBIERI, 2006, p. 389), além de propiciar mudanças sociais e culturais. Porém, essa representação não é totalmente acertada, afinal a personagem usa vestidos desde o início da trama, ficando subentendido que não precisou mudar a forma de se vestir para ser reconhecida na sociedade em que vive, permanecendo feminina, mas que precisou passar por inúmeros traumas que a transformaram, definitivamente, em protagonista. 


\section{Mediações entre os Sete Reinos e a contemporaneidade}

A partir da análise da textual, relacionamos, portanto, todas as observações feitas até aqui para mapear os sentidos que, a partir da personagem Sansa Stark, nos permitem refletir sobre os valores atribuídos ao feminino na série. Neste momento, acionamos o conceito de mediação, compreendido aqui, nesta pesquisa, como uma interpretação da realidade, para elencar os sentidos sobre o feminino contemporâneo que mais se destacaram.

Assim, encontramos três sentidos mais gerais: a) conservadorismo de gênero; b) competência como valor do feminino público; e c) moralidade masculina no contexto da feminilidade contemporânea. Essas categorias correspondem, portanto, à mediação que a série Game of Thrones faz com a sociedade contemporânea, afinal, busca em nossa realidade a inspiração para produzir seu enredo. Por isso, ficou comprovado que a representação da personagem Sansa Stark é baseada em valores amplamente difundidos em nosso cotidiano como relegar à mulher ao seu sexo biológico ou associar sua competência e moralidade a atributos masculinos.

- Conservadorismo de gênero: as distinções de gênero, discutidas na parte teórica do trabalho, nos permitem compreender que quase sempre a mulher esteve submetida por seu caráter biológico, ou seja, sua função era a de reprodutora, apenas para dar continuidade a espécie. Assim, o sexo é uma característica importante na construção da personagem e, de modo mais amplo, é temática relevante na compreensão discursiva sobre a mulher. Sansa Stark aceita sua condição de submissa, no início. Veste-se como uma lady, aprende a costurar, e fica feliz por saber desempenhar tão bem o trabalho, tem medo de que o príncipe encantado não goste de sua aparência e de que não tenha filhos homens. No entanto, começa a questionar seu papel quando tem sua primeira menstruação, o que a aterroriza, afinal, sabe que precisará cumprir seu destino a partir daquele momento. Mas, mesmo que questione seu papel, aceita casar-se, a mando de um homem e, por isso, acaba sendo violentada. Assim, é interpretada “[...] como uma menina frágil, insegura e violentada, que está presa em relações de dependência marcadas por violência e humilhação." (MULLER; SCHMIDT, 2018, p. 80). Portanto, o conservadorismo de gênero associado à personagem fica evidente nas Figuras 1, 2 e 3. Assim, podemos dizer que a série buscou na sociedade contemporânea por fatos 
concretos acerca da violência contra mulher que enriquecessem a história do ponto de vista de seus produtores e roteiristas. Por isso, há tantas cenas de violência, tanto física quanto psicológica gratuitas contra mulheres, ficando subentendido que precisam sofrer e passar por grandes traumas para ascenderem na trama, ficando evidente que as duas personagens são definidas pelo seu sexo (MURARO, 1991) ao longo de toda a trama.

- Competência como valor do feminino público: nem sempre a mulher foi reconhecida no espaço público. Foi um lento processo que só mudou a partir de mudanças na matriz de pensamento econômico. Algumas mudanças que ocorreram na sociedade, como a queda de monarquias e regimes absolutistas, a industrialização e a transformação de espaços públicos e privados a partir da urbanização, entre outros, permitiram que a mulher passasse a ser vista além do lar, ou seja, como trabalhadora e operária e, consequentemente, como agente do espaço público, lentamente ocupando diferentes ambientes e papeis sociais (BEAUVOIR, 1970). Portanto, a inserção da personagem no espaço público nos faz refletir sobre um caráter importante em suas construções narrativas: a competência. Sansa Stark é uma garota que, por ter crescido em uma sociedade patriarcal, acabou por aceitar seu destino e a sonhar com o futuro casamento, que deveria ser com um príncipe. Ela amava a vida que viria a ter, o marido, os filhos, o título de nobreza porque nunca havia saído daquela zona de conforto. No entanto, com o desenrolar da história, e após passar por traumas, ser violentada tanto física quanto psicologicamente, e ser considerada apenas como uma moeda de troca para atender aos desejos de homens que estavam ao seu redor, começa a demonstrar ter um espírito de liderança. Isso fica bem delineado na sexta e na sétima temporadas quando, após libertar-se de um marido cruel, volta para casa e é tratada como igual pelo seu meio-irmão, liderando conjuntamente com ele a casa e o vilarejo (Figuras 5 e 6). Nesse momento, ela ascende na trama e atinge um patamar outrora ocupado somente por homens, mostrando ser competente. Assim, demonstra ser uma líder nata e, isto se confirma na parte empírica estudada anteriormente, em que ela consegue se inserir em um espaço público, amplamente, masculinizado. Sansa sai, portanto, do contexto privado do lar e da família para integrar a vida pública - que antes era reservada apenas aos homens. 
- Moralidade masculina no contexto da feminilidade contemporânea: outro fator interessante na construção de sentidos da personagem é a moralidade, a qual aparece marcada pela polarização feminino-privado/masculino-público. Esse movimento reforça, ainda, a ascensão que se submete, pois passa da esfera privada do lar para a esfera pública da liderança. Em Sansa, essa mudança ocorre ao deixar o marido morrer (Figura 4). Assim, ocorre uma espécie de elastização da personalidade feminina, que deve desempenhar papéis diversos, por vezes mesmo contraditórios, numa gama variada de funções, com sucesso. Portanto, o que acontece com a personagem é uma ampliação dos ideais, pois vê a necessidade de corresponder também aos ideais próprios do espaço público - que eram, antes, restritos ao universo masculino. "[...] às voltas com a necessidade de percorrer o difícil caminho que qualquer mudança de posição subjetiva exige, as mulheres parecem ter hoje diante de si um espectro amplo de ideais a buscar alcançar." (FERNANDES, 2006, p. 2). Isso significa que, além de precisar se adaptar ao meio em que está inserida, precisa ter sucesso, independentemente do preço que tenha que pagar - no caso, a transformação da moralidade. Por isso, o ato de matar acaba sendo crucial para que a moralidade de Sansa mude. Ou seja, rompe uma barreira moral e social, já que matar é um atributo amplamente masculino no universo da série. Assim, a passagem de Sansa da vida privada à pública faz com que adquira força e, portanto, acentue certo valor masculino. É uma quebra de paradigmas, já que adquire valores vistos apenas no mundo masculino, compondo o que chamamos de identidade da mulher contemporânea, que é formada de acordo com o ambiente e valores sociais vigentes e próprios do patriarcado.

\section{Considerações finais}

É cada vez mais corriqueiro que temas como sexualidade e mulher como propriedade do homem estejam em pauta na mídia, afinal, essa “[...] é um construtor e reprodutor cultural, [...] está diretamente ligada com os sentidos que se mantêm ou se transformam nas culturas que caracterizam uma sociedade." (JORDÃO, 2011, p. 103). Assim, a série Game of Thrones, por ser um produto audiovisual relativamente novo e com uma das 
maiores audiências do canal HBO, é relevante, pois mostra uma personagem que sofre uma transformação na trama: de menina passa a ser visível perante a sociedade em que vive.

Entretanto, o que chama a atenção é o fato de a série trabalhar com inúmeras pautas referentes ao feminismo, como violência sexual, psicológica, casamento infantil e forçado e mulher como moeda de troca. Portanto, percebemos que a Game of Thrones busca trazer à baila tipos de violência que acontecem na contemporaneidade em relação à mulher. No entanto, apesar de sabermos que é necessário que exista a discussão sobre as distintas formas de violência, bem como que sejam criadas políticas públicas, acreditamos que o papel de uma série de televisão, de renome internacional e com recordes de audiência, é trazer entretenimento aos(às) telespectadores(as), e não naturalizar cenas de violência gratuita contra mulheres. Desse modo, o que percebemos é que, em Game of Thrones, o feminino somente consegue se empoderar por meio do sofrimento, ou que sempre precisa ter um homem por trás de seus sucessos, ou que adquira valores do universo masculino, se portando como um homem. A série televisiva tem como mote dar voz aos subalternos. Porém, esse foco está sendo disseminado em forma de violência generalizada, como se somente por meio do sofrimento gratuito que um marginalizado possa empoderar-se. Desse modo, inferimos que Sansa Stark passa a ser visível perante a sociedade em que vive. Ou seja, é uma passagem da vida privada - em que deveria seguir a regras impostas por alguém - à vida pública. Essa mudança faz com que adquira força e, dessa forma, acentue a percepção de uma feminilidade masculinizada, amplamente relacionada com valores contemporâneos do feminino.

É nesse sentido que podemos dizer que se trata de uma quebra de paradigmas, pois a personagem adquire valores antes restritos apenas ao mundo masculino, caracterizado como uma independência masculinizada, compondo, portanto, o que chamamos de múltiplas identidades da mulher contemporânea. Isso significa que os sentidos negociados entre a ficção e a realidade presentes em Sansa, na série, são formadas de acordo com o ambiente em que vive, valores sociais e privados impostos pela sociedade. Essa mudança nas identidades é responsável por um desenvolvimento ascendente da personagem na série - do privado para o público. Sendo assim, constatamos que Sansa Stark passa a ter posições de destaque em Game of Thrones, e essa mudança de posição só ocorre porque tem suas identidades alteradas, adquirindo valores outrora presentes no universo masculino. 


\section{Referências}

BEAUVOIR, Simone. 0 segundo sexo: fatos e mitos. São Paulo: Difusão Europeia do Livro, 1970.

BERNARDES, Walkyria. Pós-modernidade, mídia e perfil identitário feminino. In: VIEIRA, Josenia Antunes (Org.). Olhares em análise do discurso crítica. Brasília: Cepadic, , 2009, p. 75-88.

BORGES, Heloisa Porto; RODRIGUES, Rodrigo Fonseca. A tradição dos contos de fada e a sobrevivência de matrizes culturais femininas nas narrativas cinematográficas infantis. INTERthesis, Florianópolis, v. 15, n. 3, p. 109-127, 2018.

BUTLER, Judith. Problemas de gênero: feminismo e subversão da identidade. Rio de Janeiro: Editora Civilização Brasileira, 2010.

CASETTI, Francesco; CHIO, Frederico di. Análisis de la televisión: instrumentos, métodos y prácticas de investigación. Barcelona: Paidós, 1999.

DOWLING, Colette. Complexo de Cinderela. São Paulo: Melhoramentos, 2002.

ESCOSTEGUY, Ana Carolina. Stuart Hall e feminismo: revisitando relações. Matrizes, São Paulo, v. 10, n. 3, p. 61-76, set./dez. 2016.

FERNANDES, Maria Helena. A mulher elástico. Revista Viver Mente \& Cérebro, São Paulo n. 161, p. 28-33, 2006.

FREITAS, Ana. Psicodinâmica das cores em Comunicação. Nucom, Limeira, ano 4, n. 12, p. 118, 2007.

GARCIA, Carla. Breve história do feminismo. São Paulo: Claridade, 2011.

GIRLS NOT BRIDES. 2017. Disponível em: https://www.girlsnotbrides.org/. Acesso em: 14 jun. 2018.

GROENHOLM, Micco. Color psicology. 2010. Disponível em: https://bit.ly/33274kM.

Acesso em: 28 nov. 2018.

HALL, Stuart. Cultura e representação. Rio de Janeiro: Apicuri, 2016.

HALL, Stuart. Notas sobre a desconstrução do "popular". In: SOVIK, Liv (Org.). Da diáspora: identidades e mediações culturais. Belo Horizonte: UFMG; Brasília: Unesco, 2003, p. 247 264.

HARAWAY, Donna. "Gênero" para um dicionário marxista: a política sexual das palavras. Cadernos Pagu, Campinas, n. 22, p. 201-246, jan./jun. 2004.

HEILBORN, Maria Luiza. De que gênero estamos falando? Sexualidade, Gênero e Sociedade, Rio de Janeiro, ano 1, n. 2, 1994. 
HIBBERD, James. 'Game of Thrones' producer explains Sansa's wedding night horror. Entertainment Weeky, New York, May 2015. Disponível em: https://bit.ly/2IkLcZT. Acesso em: 19 mar. 2019.

JOHNSON, Richard. 0 que é, afinal, Estudos Culturais? In: JOHNSON, Richard; ESCOSTEGUY, Ana Carolina; SHULMAN, Norma. 0 que é, afinal, Estudos Culturais? 3. ed. Belo Horizonte: Autêntica, 2006, p. 7-132.

JORDÃO, Janaína Vieira de Paula. Trabalhadoras domésticas: representação midiática e identidade. Sociedade e Cultura, Goiânia, v. 14, n. 1, p. 99-108, jan./jun. 2011.

LARRAÍN, Jorge. El concepto de identidade. FAMECOS, Porto Alegre, v. 10, n. 21, p. 30-42, ago. 2003.

LOURO, Guacira. Corpo, gênero e sexualidade: um debate contemporâneo na educação. 3. ed. Petropólis: Vozes, 2007.

MACEDO, José Rivair. A mulher na Idade Média. São Paulo: Editora Contexto, 2002.

MARTÍN-BARBERO, Jesús. Dos meios às mediações: comunicação, cultura e hegemonia. Rio de Janeiro: Editora UFRJ, 2001.

MODLESKI, Tania. Feminism without Women: culture and criticism in a "postfeminist" Age. New York: Routledge, 1991.

MOREIRA, Virgínia; BATISTA, Mércia. "PRONTO, AGORA JÁ SOU MOÇA": símbolos e significados que marcam o corpo menstruado. Caderno Espaço Feminino, Uberlândia, v. 29, n. 2, p. 27-51, jul./dez, 2016.

MOSCOVICI, Serge. Representações sociais: investigação em psicologia social. Petrópolis: Vozes, 2003.

MULLER, Janaína; SCHMIDT, Saraí. Cante, passarinho: gênero, heteronormatividade e violência a partir da abordagem da personagem Sansa Stark em fanfictions. Mídia e Cotidiano, Niterói, v. 12, n. 2, p. 69-96, 2018.

MURARO, Rose. Breve introdução histórica [a obra O Martelo da Feiticeiras]. In: KRAMER, Heinrich; SPRENGER, James. 0 martelo das feiticeiras. Rio de Janeiro: Rosa dos Tempos, 1991, p. 5-17.

NOGUEIRA, André. Sem amor e nem calor: o casamento arranjado entre Dom João VI e Carlota Joaquina. São Paulo: Aventuras na História, 2019.

O GLOBO. Final de 'Game of thrones' bate recorde de audiência da HBO nos Estados Unidos. Rio de Janeiro: O Globo, 2019. 
ORÓZCO-GÓMEZ, Guillermo. Medios, audiencias y mediaciones. Comunicar, Guadalajara, v. 5, n. 8, p. 25-30, 1997.

PEREIRA, Ana; SOUZA, Débora; CARDOSO, Flaviane. As Daenerys Targaryen do século XXI. In: COLÓQUIO NACIONAL REPRESENTAÇÕES DE GÊNERO E DE SEXUALIDADES, 13., 2018, Campina Grande. Anais [...]. Campina Grande: Realize Eventos e Editora, 2018.

PERROT, Michelle. Mulheres Públicas. São Paulo: Fundação Editora da UNESP, 1998.

PISCITELLI, Adriana. Gênero: a história de um conceito. In: ALMEIDA, Heloisa Buarque; SZWAKO, José (Org.). Diferenças, igualdade. São Paulo: Berlendis \& Vertecchia, 2009, p. 116-148.

PISCITELLI, Adriana. Recriando a (categoria) mulher? In: ALGRANTI, Leila (org.). A prática feminista e o conceito de gênero. Campinas: IFCH-Unicamp, 2002, p. 1-25.

REIMER, Ivoni Richter. Patriarcado e economia política: o jeito romano de organizar a casa. In: REIMER, Ivoni Richter (org.). Economia no mundo bíblico: enfoques sociais, históricos e teológicos. São Leopoldo: CEBI; Sinodal, 2006. p. 72-97.

SABAT, Ruth. Filmes Infantis e a Produção Performativa da Heterossexualidade. 2003. Tese (Doutorado em Educação) - Faculdade de Educação, Universidade Federal do Rio Grande do Sul, Porto Alegre, 2003.

SCOTT, Joan. Gênero: uma categoria útil de análise histórica. Revista Educação e Realidade, Porto Alegre, v. 20, n. 2, p. 71-99, jul./dez. 1995.

SGARBIERI, Astrid. Representações do gênero feminino na mídia impressa. Estudos Linguísticos, São Paulo, v. 35, p. 386-391, 2006.

SPECTOR, Caroline. Poder e feminismo em Westeros. In: LOWDER, James (Org.). Além da muralha. São Paulo: Editora Leya, 2015, p. 117-128.

THE GLOBAL GENDER GAP REPORT 2017. 2017. Disponível em: https://bit.ly/2gVYk9P. Acesso em: 19 mar. 2019.

TOMAZETTI, Tainan; CORUJA, Paula. Relações de gênero nos estudos de recepção e consumo midiático: perspectivas de teses e dissertações em comunicação entre 2010 e 2015. Novos Olhares, São Paulo, v. 6, n. 1, p. 115-128, 2017.

VARIA, Nisha. Meeting the Global Development Goals' Promise to Girls. 2015. Disponível em: https://bit.ly/1UqqB42. Acesso em: 20 nov. 2018.

VIEIRA, Josênia Antunes. A identidade da mulher na modernidade. Revista Delta, São Paulo, v. 21, n. especial, p. 207-238, 2005.

WILLIAMS, Raymond. Marxismo e literatura. Rio de Janeiro: Zahar, 1979. 


\title{
Female Representations in Game of Thrones: Mediations between Seven Kingdons and the Contemporary
}

\begin{abstract}
The present research questions how the feminine identities of the character of Sansa Stark, of Game of Thrones are represented, and which senses about the contemporary feminine are mobilized by the series. For this, we seek to observe our object through the category character and interactions through the textual analysis proposed by Casetti and Chio (1999). After this, we triggered the concept of mediation, coming from a comparison between Williams (1979), Orózco-Gómez (1997) and Martín-Barbero (2001), through the categories gender, competence and morality, and we perceive that the series seeks to problematize types of violence occurring contemporaneously in relation to the feminine, such as sexual, psychological or physical violence, child marriage and woman as a bargaining chip. Thus, throughout the seasons, the personage is pictured in order to ascend, but only after going through numerous types of violence. Therefore, the negotiated senses between fiction and reality present in Sansa, in the series, are formed according to the environment in which they live, social and private values imposed by society.
\end{abstract}

\section{Keywords}

Feminine Identity. Gender. Representation. Mediation. Game of Thrones.

\section{Autoria para correspondência}

Andréa Corneli Ortis

ortis.andrea@gmail.com

\section{Como citar}

ORTIS, Andréa Corneli; LISBÔA FILHO, Flavi Ferreira. Representações femininas em Game of Thrones: mediações entre os sete reinos e a contemporaneidade. Intexto, Porto Alegre, n. 52, e-93331, jan./dez. 2021. DOI: http://dx.doi.org/10.19132/1807-8583202152.93331

Recebido em 30/05/2019

Aceito em 30/11/2019 